\title{
Når fårene forlader flokken. En religionssociologisk analyse af udmeldelser fra folkekirken
}

\author{
PETER LÜCHAU
}

\begin{abstract}
ENGLISH SUMMARY: Membership of the Danish National Church has declined steadily but has not until now been the subject of sociological analysis. Using data from governmental databases housed at Statistics Denmark the article analyze individuals who disaffiliated from the Danish National Church from 2003 to 2007. Secularization theory is used as the starting point for the analysis. Individuals who disaffiliated were generally younger, more affluent, more educated, more urbanized and more often living with non-members than the rest of the population. Age differences between the disaffiliated and the rest of the population suggested that disaffiliation was the result of a life-cycle effect rather than a generational effect. It was also shown that nonmembers tended not to baptize their children while members did. Therefore it must be concluded that the declining membership of the Danish National Church is the result of a general societal development.
\end{abstract}

DANSK RESUME: Artiklen analyserer ved hjælp af registerdata fra Danmarks Statistik individer som har meldt sig ud af folkekirken i perioden 2003 til 2007. Med udgangspunkt $i$ sekulariseringsteori må det forventes, at de udmeldte var yngre, mere velhavende, højere uddannede og mere urbaniserede end resten af befolkningen. Analysen af data bekræfter forventningen med visse forbehold. De udmeldte var mere velhavende, højere uddannede og mere urbaniserede end resten af befolkningen. De var også generelt yngre; men de udmeldtes aldersprofil antyder, at udmeldelse var et livscyklus fænomen og ikke et generationsfænomen som teorien forventede. Det kunne også konstateres, at medlemskab af folkekirken og mangel på samme videreførtes fra forældre til børn. Resultaterne antyder, at folkekirkens dalende medlemstal er resultatet af en generel samfundsudvikling. 
KEYWORDS: Sociology of Religion, Danish National Church, secularization, disaffiliation, quantitative data

\section{Indledning}

Den Danske Folkekirke mister løbende medlemmer; men i modsætning til i Finland, Norge og Sverige har medlemstabet ikke hidtil været genstand for analyse. Uden en sådan analyse er det umuligt at sige noget om karakteren af medlemstabet eller om de mulige årsager bag. Problemstillingen omkring folkekirkens dalende medlemstal er kompleks og inkluderer bl.a. demografi, sociale forhold, religiøsitet, værdier og socioøkonomiske faktorer og kan angribes fra såvel en kvalitativ som en kvantitativ vinkel. Her vil analysen være kvantitativ for at give et generelt overblik, og fokus vil være på en begrænset del af den samlede problemstilling nemlig gruppen af individer som har valgt at melde sig ud af folkekirken. Konkret vil artiklen ved hjælp af registerdata fra Danmarks statistik analysere de socioøkonomiske faktorer bag udmeldelser fra folkekirken i perioden 2003 til 2007.

\section{Folkekirkens medlemsudvikling}

Antallet af medlemmer i den danske folkekirke har været svingende de sidste 40 år. Fra 1970 til 1978 steg folkekirkens medlemstal fra ca. 4.725 .000 medlemmer til ca. 4.812.000 som følge af en generel befolkningstilvækst i Danmark. Fra 1978 til 1993 dalede medlemstallet fra ca. 4.812 .000 til ca. 4.544.000 medlemmer bl.a. som en konsekvens af et fald i antallet af etniske danskere. Fra 1993 til 2007 vedblev folkekirkens medlemstal at dale, og i 2007 var ca. 4.499 .000 individer medlemmer af folkekirken. Medlemsudviklingen fra 1970 til 2007 var således kendetegnet ved tre forskellige perioder. Der var en svag vækst fra 1970 til 1978 (ca. 10.000 flere medlemmer pr. år), et kraftigt fald fra 1978 til 1993 (ca. 18.000 færre medlemmer pr. år) og et svagere fald fra 1993 til 2007 (ca. 3.000 færre medlemmer pr. år). Selvom tallene er forbundet med en vis usikkerhed, demonstrerer de, at folkekirkens medlemsudvikling er en forholdsvis dynamisk størrelse. Det er derfor vanskeligt at lave langtidsprognoser om folkekirkens medlemstal i fremtiden. Folkekirkens medlemsudvikling er således hverken entydig eller let forudsigelig.

Årsagerne bag folkekirkens dalende medlemstal må nødvendigvis findes blandt de individer, som enten forlader folkekirken eller aldrig bliver meldt ind. Der er ikke sket ændringer i den danske religionslovgivning i de sidste 40 år, som kan forklare det dalende medlemstal. Siden i hvert fald 1993 har antallet af indfødte danskere været stabilt, hvorfor demografiske ændringer heller ikke kan forklare det dalende medlemstal. Når folkekirken har fået færre medlemmer de sidste tre årtier, skyldes det en kombination af medlemmer som dør, nyfødte som ikke bliver døbt og med- 
lemmer som melder sig ud. Disse tre grupper udgør således de individer, som er en del af kirkens dalende medlemstal, og som derfor må studeres for at finde årsagerne bag udviklingen. At studere medlemmer, som dør, giver ikke mening, da deres udmeldelse er ufrivillig. At studere udøbte giver heller ikke mening, da beslutningen ikke er deres, men deres forældres. At studere forældre, som navngiver deres børn, giver mening; men desværre er det meget vanskeligt at sample denne gruppe. At studere udmeldte giver god mening, da beslutningen er deres egen, og i modsætning til forældre som navngiver deres børn kan de forholdsvist let samples via Danmarks statistiks registre.

At studere de udmeldte fortæller naturligvis ikke hele historien bag folkekirkens dalende medlemstal; og det er værd at bemærke, at gruppen af børn, som navngives, er større end gruppen af udmeldte ifølge den officielle kirkestatstik fra 2007. Med andre ord står forældre, der undlader at døbe deres børn, for en større del af kirkens dalende medlemstal end gruppen af udmeldte.

\section{Sekularisering}

Set fra en religionssociologisk synsvinkel er folkekirkens medlemstab interessant, fordi den er en kirke i sociologisk forstand. Den er en hierarkisk organiseret religiøs institution, som er åben for alle, og som understøtter samfundets status quo. Medlemskab af folkekirken er således ikke kun et udtryk for religiøsitet, men også for institutionel præference. Det kan dermed, bl.a., tolkes som et udtryk for individets støtte til folkekirken som samfundsinstitution, og dermed dens ret til at være tilstede og ytre sig i det offentlige rum. Dermed bliver medlemskab af folkekirken et eksempel på det, Dobbelaere kalder church involvement (Dobbelaere 2002). Church involvement er det centrale mål for sekularisering på individniveau i Dobbelaeres analyser og måles via indikatorer som kirkegang, kristen tro og kirkemedlemskab (se fx Jagodzinski \& Dobbelaere 1995). Det er et mål for individets grad af normativ integration i en given kirke, altså om individet har overtaget kirkens værdier og normer. Forventningen hos Dobbelaere er, at som samfundet sekulariseres, vil individets normative integration i kirken mindskes.

Sekularisering er den proces, hvorved religionen mister sin betydning for samfundet og individet. På samfundsplan indebærer det, at kirken ikke længere kan integrere og legitimere samfundet som helhed (Dobbelaere 2002). Religionen bliver mindre vigtig i styringen af ikke-religiøse dele af samfundet. Økonomi, politik og videnskab gør sig fri af religionens magt, bliver autonome og kommer derved udenfor kirkens rækkevidde. Dertil kommer, at religiøse institutioner, fx folkekirken, og religiøse roller, fx præster, mister prestige generelt (Bruce 2002, 3). På individplan indebærer sekularisering, at færre individer er medlemmer af en kirke, deltager i kristne ritualer eller tror på kirkens dogmer og trosforestillinger (Bruce 2002; Norris \& Inglehart 2004). Kirkens mindskede autoritet og prestige medfører, at færre indivi- 
der, også selvom de stadig måtte være religiøse, vil leve deres liv influeret af de religiøse regler kirken opstiller. I sidste ende vil et stigende antal individer leve deres liv, uden at religion er en faktor (Berger 1967; Bruce 2002).

Der er bred enighed blandt sekulariseringsteoretikere om at sekularisering er et produkt af samfundets funktionelle differentiering. I middelalderen var det nærmest umuligt at skille det religiøse fra det sekulære. Religion, politik, økonomi, videnskab etc. var integrerede, og kirken havde noget at skulle have sagt i alle dele af individets og samfundets liv. I sidste halvdel af det 17. århundrede begyndte en udvikling, som betød, at samfundet i stigende grad blev delt op i autonome subsystemer efter funktion (Luhmann 1977, 229). Som de økonomiske, politiske og videnskabelige subsystemer begyndte at fungere efter deres egne regler, mistede religionen og dens repræsentant kirken evnen til at påvirke dem og blev mere og mere isoleret i sin egen niche. Resultatet blev, at det religiøse næsten kun fandtes i det nationale og det private (Berger 1967) og senere næsten kun i det private dvs. familien (Luckmann 1967).

Subsystemerne opnåede ikke autonomi allesammen på samme tid. Udviklingen skete gradvist, men startede i det økonomiske subsystem (Berger 1967, 129). Det betød, at kirkens indflydelse langsomt blev indskrænket, som subsystem efter subsystem blev autonome. Følger man denne tankegang, må det formodes, at visse dele af samfundslivet er mere sekulariserede end andre. Antager man et vist sammenspil mellem udviklingen på samfundsniveau og individniveau, må det også følge, at visse individer er mere sekulære end andre. Individer knyttet til sekulære subsystemer vil have tendens til at være sekulære, mens individer knyttet til mindre sekulære subsystemer vil have tendens til at være religiøse.

Når sekulariseringsteori anvendes som teoretisk udgangspunkt i indeværende artikel, er det alene, fordi den passer godt til den konkrete analyse, udmeldelse fra en nordeuropæisk kristen kirke. Det er nemlig ikke med urette, at sekulariseringsteori er en af de mest kritiserede teorikomplekser inden for religionssociologien i dag. Kritikken kan groft set deles op i to typer. Den første er en kritik af selve teoriens formulering. Som Shiner gør opmærksom på, er der ikke én, men flere definitioner af sekularisering (Shiner 1967). Ser man nærmere på de forskellige definitioner, viser de sig ofte at være hinanden modsigende. Kühle kan fx demonstrere, at det samme empiriske fænomen, religion i det politiske rum, på én og samme tid kan bruges til at såvel be- som afkræfte sekularisering (Kühle 1999, 52). På den ene side kan man sige, at politiske debatter om religion er udtryk for sekularisering, fordi religion nu optræder på politiske vilkår; men man kan på den anden side sige, at det er udtryk for en afkræftelse af sekulariseringstesen, da religion netop burde forsvinde fra det politiske subsystem som følge af samfundets funktionelle differentiering. I så fald kan sekulariseringsteori ikke falsificeres og er derfor ikke at betragte som en videnskabelig teori. Løsningen på dette problem er som i indeværende artikel at lægge sig fast på én fortolkning af sekulariseringsteori og sørge for, at den falsificerbar. 
Den anden type kritik går ikke på det teoretiske, men det empiriske. Berger, som var en af de store sekulariseringsteoretikere i 1960'erne, endte med at tage afstand fra sin egen teori - ikke fordi han afviste samfundets funktionelle differentiering, men fordi den forventede religiøse nedgang udeblev. Verden er ifølge Berger lige så religiøs, som den altid har været (Berger 1997, 3), og han nævner såvel en muslimsk vækkelse i bl.a. Mellemøsten og en tilsvarende pinsevækkelse i Sydamerika som eksempler. Berger vedgår, at vest- og nordeuropæerne er blevet mindre religiøse; men de er netop undtagelsen, som bekræfter reglen (ibid., 8). Kritikken kan bedst imødekommes ved at erkende, at sekularisering ikke er et universelt fænomen, og ved kun at anvende begrebet i analyser af religion i Vest- og Nordeuropa. Samtidig er det også essentielt at betragte sekularisering som et empirisk spørgsmål og ikke et etableret faktum. Som det netop er tilfældet i indeværende artikel, bør sekularisering betragtes som en teoretisk antagelse, som skal efterprøves empirisk og om nødvendigt afkræftes, hvis teorien ikke passer med de empiriske data.

\section{Konkrete forventninger til sekularisering}

Det må forventes, at ældre generationer er mere kirkeligt religiøse end yngre generationer. Det skyldtes, at værdier og dermed også religiøsitet ofte er styret af en generationseffekt (Gundelach 2011, 18-20). Hver generation er religiøs på sin måde, og denne religiøsitet følger generationen gennem hele dens levetid. Religiøse forandringer bliver derved produktet af påvirkninger i de formative år. Da sekularisering er sket gradvist over tid, må det forventes, at hver generation er blevet stadig mere sekulariseret. Jo yngre en generation er, jo mere sekulariseret må den antages at være.

Det må forventes, at individer med tilknytning til det økonomiske subsystem er mindre religiøse end andre. Det skyldtes, som nævnt ovenfor, at det økonomiske subsystem var det første, som skilte sig fra det religiøse subsystem. De fleste analyser af sekularisering har valgt at tolke individuel rigdom som et udtryk for graden af tilknytning til det økonomiske subsystem. Det er naturligvis diskutabelt, og fx beskæftigelse i den finansielle sektor ville være et mere præcist mål. Argumentet for alligevel at påstå, at velhavende individer skulle være mindre kirkeligt religiøse, er todelt. Dels har de fleste kristne retninger traditionelt forbundet askese med religiøs styrke. Rigdomme sås som forstyrrende for den sande tro og blev derfor undgået. Dels har kristendom været en støtte for de underprivilegerede. Som samfundsudviklingen løftede de fleste over fattigdomsgrænsen, blev deres religiøsitet svækket, fordi den livsstil, som understøttede religiøsiteten, forandrede sig (Bruce 2002, 25-26). Et alternativt argument kunne være, at underprivilegerede individer bruger religion for at kompensere for manglende materiel og fysisk sikkerhed. Som deres økonomiske forhold forbedres, forsvinder deres behov for religion, fordi de kan købe sig til materiel og fysisk sikkerhed (Norris \& Inglehart 2004, 13-17.29). 
Det må forventes, at individer, hvis måde at tænke på er stærkt influeret af videnskab, er mindre religiøse end andre. Den primære årsag er, at videnskab inkorporerer en bestemt form for rationalitet, idet den påstår, at alt har en forklaring og at alt er styret af observerbare kausalforhold. Dette er ikke befordrende for religion og antyder, at det eneste, som ikke er til diskussion, er kravet om effektivitet (Bruce 1996, 48). Alt andet kan der sættes spørgsmålstegn ved, selv Gud. Læg dertil, at videnskab giver bedre forklaringer på verdensfænomener end kirken og tilmed kan bekræfte rigtigheden af sine forklaringer via praktiske resultater (Wilson 1966:42). Det er dog vigtigt at forstå, at det er den rationelle måde at tænke på, som er undergravende for religion, og ikke videnskab i sig selv. Videnskab har en indirekte indflydelse på religion snarere end en direkte (Martin 1969, 116-117). Videnskab undergraver religion i kraft af sit fokus på rationalitet; men dens styrke og indflydelse får den gennem sin social base via de individer, som er videnskabeligt skolet (Bruce 1996:48-50). Hermed også sagt, at individer, som er videnskabeligt skolet, alt andet lige vil have tendens til at tænke rationelt og derved være mindre religiøse end andre. Det er altså den rationelle tænkemåde og ikke en eventuel tilknytning til det videnskabelige subsystem, som er det afgørende. I praksis må det derfor forventes, at individer med en universitetsuddannelse er mindre religiøse end andre, og at jo længere uddannelsen, er jo mindre religiøse er de.

Det må forventes, at individer, som bor i en storby, er mindre religiøse end individer, som bor i landområder eller i mindre byer. Ligesom sekularisering påvirker samfundets subsystemer i forskellige tempi, spreder sekularisering sig også i forskellige tempi ud over landet. Urbanisering ødelægger de strukturer, som understøtter kirkerelateret religion. På landet derimod er disse strukturer stadig til stede. En variant af dette argument er, at agrare strukturer forbliver udbredte på landet og i mindre byer. Individer med tilknytning til agrarer strukturer bliver ved med at være religiøse. Postindustrielle strukturer derimod er udbredte i større byer, og individer som er knyttet til disse bliver mindre religiøse (Gundelach \& Riis 1992). En anden variant af dette argument fokuserer på holdningsmæssig orientering. Individer, som er orienterede mod det lokale, er mere religiøse end individer, som er kosmopolitisk orienterede. Da lokalt orienterede individer er at finde på landet og i mindre byer, mens de kosmopolitisk orienterede er at finde i storbyer (Roof 1978), betyder det, at individer alt andet lige er mere religiøse på landet end i storbyer. Uanset hvilket argument man vælger, det strukturelle eller det hældningsmæssige, er forventningen, at individer i storbyer er mindre religiøse end individer alle andre steder.

Tilslut må det forventes, at individer, som lever sammen med en a-religiøs partner, er mindre religiøse end andre. Som sekularisering skrider frem, henvises det religiøse til sin egen lille niche uden social forankring i samfundet som helhed. Den sociale forankring kan dog bestå i det private såsom venner og omgangskreds, men nok primært i kernefamilien (Luckmann 1967, 106; Berger 1967, 133-134). Når religion ikke længere har en social forankring i samfundet som helhed, kan kirken ikke 
længere påvirke individer religiøst. Individer kan vælge at få bekræftet deres religiøsitet $\mathrm{i}$ kirken $\mathrm{fx}$ ved at gå til gudstjeneste eller være medlem; men religiøsiteten har de med hjemmefra. Det indebærer, at individets religiøsitet står og falder med den sociale støtte, deres religiøsitet har i hjemmet. Eller sagt på en anden måde, så er sandsynligheden for, at individer er religiøse, størst, hvis dem, de lever sammen med, det være sig en partner eller forældre, også er det. Og omvendt er sandsynligheden for, at individer er a-religiøse, størst, hvis de lever sammen med andre areligiøse individer.

\section{Hypoteser}

Ud fra de konkrete forventninger til sekularisering må det antages, at det ikke er tilfældigt, hvem som melder sig ud af folkekirken. Visse grupper i samfundet er mere sekulariserede end andre; og det må alt andet lige forventes, at jo mere påvirket individer er af sekularisering, jo mere tilbøjelige er de til at melde sig ud af folkekirken. Medlemskab af folkekirken er trods alt et klassisk eksempel på church involvement. Ud fra ovenstående kan opstilles følgende hypoteser om de individer som meldte sig ud af folkekirken i perioden 2003 til 2007:

$\mathrm{H}_{1}$ : Udmeldte var yngre end resten af befolkningen.

$\mathrm{H}_{2}$ : Udmeldte var mere velhavende end resten af befolkningen.

$\mathrm{H}_{3}$ : Udmeldte var højere uddannede end resten af befolkningen.

$\mathrm{H}_{4}$ : Udmeldte boede oftere i større byer end resten af befolkningen.

$\mathrm{H}_{5}$ : Udmeldte boede oftere sammen med ikke-medlemmer end resten af befolkningen.

Når yngre generationer er mere sekulariserede end ældre generationer, følger det naturligt, at individer, som melder sig ud, vil have en tendens til at være yngre end befolkningen som helhed. Eftersom videnskab undergraver religion, bliver individer, som er videnskabeligt skolede, mere sekulariserede end andre. Konkret burde det resultere i, at de udmeldte i højere grad end resten af befolkningen har en længerevarende uddannelse. Sammenhængen mellem indtægt og sekularisering er forholdsvis ligefrem, og det må derfor forventes, at de udmeldte i højere grad end resten af befolkningen befinder sig i de højere indkomstgrupper. Eftersom at urbanisering gør individer mere sekulariserede end individer, som bor på landet eller mindre byer, må det forventes, at der er flere blandt de udmeldte, som er bosat i en storby, end blandt resten af befolkningen. Da religionens sociale forankring kun findes i kernefamilien, må det forventes, at individer, som melder sig ud af folkekirken, oftere lever sammen med en a-religiøs partner end resten af befolkningen. 


\section{Undersøgelsesgruppen}

I det følgende vil gruppen af udmeldte fra folkekirken blive analyseret i et forsøg på at afdække årsager bag folkekirkens medlemstab. Andre grupper kunne som nævnt ovenfor have været analyseret; men valget er faldet på de udmeldte af praktiske og analytiske årsager.

At analysere individer, som aktivt har meldt sig ud af folkekirken giver god mening rent analytisk. Ligesom forældre, der navngiver deres børn, burde gruppen af udmeldte tilhøre de mere sekulariserede grupper i det danske samfund. En analyse af de udmeldte burde derfor kunne sige noget om de socioøkonomiske faktorer, som ligger bag folkekirkens medlemstab. Analysen kan naturligvis kun sige noget om de udmeldtes egen udmeldelse og ikke noget om, hvorvidt de vil videreføre deres manglende medlemskab til deres børn. At analysere gruppen af udmeldte har også den praktiske fordel frem for at analysere forældre, som har navngivet deres børn, at det er forholdsvist ukompliceret at sample dem repræsentativt via Danmarks Statistiks registre, bl.a. fordi der kun skal søges oplysninger om individerne selv.

\section{Metodediskussion}

Målet med indeværende analyse er at lave en repræsentativ kvantitativ analyse af individer, der har meldt sig ud af folkekirken. En sådan analyse har ikke tidligere været lavet. Der har været lavet en begrænset analyse, som dækkede Århus (Sundback 1989), og en mere impressionistisk analyse af folkekirkens dalende medlemstal (Kleinbeck 2008).

Hvis analysen skal være repræsentativ, er den i sagens natur nødt til at være kvantitativ. Eksisterende samfundsvidenskabelige spørgeskemaundersøgelser såsom Den Danske Værdiundersøgelse eller International Social Survey Programme kan desværre ikke anvendes. Deres samplestørrelser er for små til at fange de meget få danskere, som melder sig ud af folkekirken. En dedikeret survey rettet mod udmeldte ville kunne løse problemet, men er desværre ret dyr. Et markant billigere alternativ er at analysere data fra de offentlige registre samlet hos Danmarks Statistik. Danmarks statistik samler alle oplysninger, det offentlige har om herboende individer. Disse oplysninger inkluderer diverse socioøkonomiske karakteristika såsom uddannelse, indkomst, bopælskommune, alder, køn, civilstand etc. De inkluderer også medlemskab af folkekirken, idet denne oplysning bruges ved indkrævning af kirkeskat.

Svagheden ved at anvende registerdata til analysen er, at der kun kan analyseres på socioøkonomiske karakteristika. Der kan altså ikke siges noget om de udmeldtes subjektive motiver for at melde sig ud. Der kan heller ikke siges noget om deres værdier og holdninger og disses eventuelle indflydelse på beslutningen om at melde sig ud af folkekirken. For at kunne analysere såvel subjektive udmeldelsesmotiver 
som værdier er det nødvendigt med en spørgeskemaundersøgelse rettet specifikt mod udmeldte. Alternativt kan man analysere individer, som må formodes at være mere tilbøjelige til at melde sig ud (se fx Lüchau 2012). Der findes en række nordiske studier af udmeldte og udmeldelsestilbøjelige individer, som viser, at religiøsitet og subjektiv tilknytning til en kirke er hovedfaktorer bag en eventuel udmeldelse (for en gennemgang af disse nordiske studier, se Lüchau \& Andersen 2012).

Kvantitative undersøgelser kan med held suppleres med kvalitative undersøgelser af motiver bag udmeldelse af folkekirken. Sådanne undersøgelser kan naturligvis ikke sige noget om gruppen af udmeldte som helhed, men de kan antyde de personlige overvejelser, der ligger bag en udmeldelse, og kaste lys over, hvordan udmeldelsen indgår i interviewpersonens livshistorie. Kvalitative undersøgelser fra Finland (se Niemelä 2007) og Sverige (omtalt i Bromander 2005, 14) viser fx, at udmeldelse er en kompliceret proces, der involverer ikke én, men flere bevæggrunde, og som er kulminationen på en længere fremmedgørelsesproces.

Indeværende analyse af udmeldte fra folkekirken baseret på registerdata ville kunne styrkes ved at blive suppleret med andre typer af undersøgelser. Såvel kvantitative spørgeskemaundersøgelser som kvalitative interviews ville kunne kaste lys over andre aspekter af udmeldelsen end de socioøkonomiske karakteristika, som er fokus i indeværende analyse. Fordi sådanne undersøgelser desværre ikke foreligger for Danmark, er et alternativ at støtte sig til nordiske undersøgelser på området, når resultaterne skal tolkes. Fordi de nordiske lande ligner hinanden, hvad religion og religiøsitet angår, burde nordiske undersøgelser kunne sætte de danske resultater i perspektiv.

\section{Data}

Data til analysen er et udtræk fra Danmarks Statistiks databaser, velvilligt finansieret af Forskningsrådet for Samfund og Erhverv. Udtrækket er en totaltælling, dvs. at den inkluderer samtlige individer bosat i Danmark, som meldte sig ud af folkekirken i årene 2003 til 2007. Udtrækket blev konstrueret ved at udtage alle individer bosat i Danmark, som var medlemmer af folkekirken i 2002, men som på et tidspunkt i årene 2003 til 2007 skiftede status fra medlem til ikke-medlem.

Da de nordiske lande ligner hinanden religiøst, set må det antages, at kun meget få udmeldelser fra den danske folkekirke er resultatet af politiske debatter, bispeudtalelser eller af en pludselig indskydelse hos individet. Der burde således ikke være store forskelle i motivationen for at melde sig ud fra år til år, hvorfor udtrækket af udmeldte fra 2003 til 2007 vil blive analyseret som en samlet gruppe.

Udover medlemskab af folkekirken indgår også en række socioøkonomiske variable i registerudtrækket. Det drejer sig om uddannelse, indkomst, bopælskommune, alder, køn, civilstand, eventuelle børn og eventuel samlever. Meningen er, at disse skal fungere som uafhængige variable i analysen og dermed forklare, hvorfor indivi- 
der vælger at melde sig ud af folkekirken. Samtidig passer disse variable godt med sekulariseringsteoriens forventninger, som netop fokuserer på socioøkonomiske faktorer som forklaring på mindsket church involvement.

For at kunne sammenligne de udmeldte med resten af den danske befolkning blev udtrukket et repræsentativt udsnit på 10 pct. af befolkningen. Disse ca. 540.000 individer fungerer således som kontrolgruppe i analysen.

\section{Medlemskab af folkekirken}

I det følgende vil udmeldelse fra folkekirken blive tolket som et udtryk for et tab af church involvement, dvs. en svigtende normativ integration i folkekirke. Denne tolkning kræver naturligvis, at individer ikke melder sig ud af folkekirken blot for at melde sig ind i et andet religiøs trossamfund, fx en frikirke. I Den Europæiske Værdiundersøgelse fra 2008 angav ca. 2 pct. af danskerne, at de var medlemmer af et andet trossamfund end folkekirken. Dette var den laveste andel siden 1981, hvor værdiundersøgelse startede. Andelen af danskerne, som var medlemmer af et trossamfund uden for folkekirken, har altså været støt dalende siden 1981. Derfor må det også antages, at langt størstedelen af de udmeldte i indeværende undersøgelse ikke har meldt sig ind i et andet trossamfund efter at have forladt folkekirken. Derved er sandsynliggjort, at udmeldelse af folkekirken kan tolkes som et udtryk for svigtende church involvement.

Oplysningerne om medlemskab af folkekirken i Danmarks Statistiks registre kommer fra skattevæsenet. Oplysningen registreres som nævnt af hensyn til at kunne inddrive kirkeskat fra kirkens medlemmer. Der er dog tale om en dobbelt registrering, idet oplysning om medlemskab også registreres i de lokale kirkebøger i de relevante sogne. Det betyder, at det er teoretisk muligt at betale kirkeskat uden at være medlem af folkekirken på grund af fejlregistrering hos skattevæsenet. Centralt på første side af selvangivelsen står, om man betaler kirkeskat. Skulle et individ fejlagtigt betale kirkeskat, har vedkommende mulighed for opdage det og få fejlen rettet. Det er svært at argumentere for, at ikke-medlemmer skulle ønske at betale kirkeskat; men det er næppe alle fejlregistrerede som har opdaget at de gør det. Det burde dog med rimelighed kunne antages, at det altovervejende flertal af individer, som har meldt sig ud af folkekirken, ifølge Danmarks statistiks registre var medlemmer til at starte med og ikke kun har været meldt ind på grund af en fejl i skattevæsenets registrering.

\section{Udmeldelser af folkekirken 2003-2007}

I følge udtrækket fra Danmarks Statistik meldte 48.499 danskere sig ud af folkekirken i årene 2003 til 2007. Antallet af udmeldelser svingede fra år til år (Tabel 1). Det høje- 
ste antal var i 2007, hvor 11.470 meldte sig ud, og det laveste i 2006, hvor 8.050 meldte sig ud af folkekirken. Af de 48.499 udmeldte var 1.123 afgået ved døden inden 2007 og derfor fjernet fra analyserne. Som en kuriositet kan nævnes, at 1.307 individer meldte sig ud af folkekirken blot for at melde sig ind igen senere og nogle sågar ud igen efter denne indmeldelse. Det kan også nævnes, at der for 1.557 individer manglede oplysninger om deres folkekirkemedlemskab mindst ét år fra 2003 til 2007. Disse individer er stadig med i analyserne; men de antyder, at selv en totaltælling, som der her er tale om, har usikkerheder i data. Usikkerheden er dog stadig langt mindre, end hvis der havde været tale om et sample af udmeldte.

\begin{tabular}{ll} 
År & Antal \\
\hline 2003 & 10557 \\
2004 & 9757 \\
2005 & 8665 \\
2006 & 8050 \\
2007 & 11470 \\
\hline Tabel 1: Udmeldelser fra folkekirken 2003 til 2007 (i rå tal) \\
Kilde: Danmarks Statistik
\end{tabular}

Antallet af udmeldte i registerudtrækket er højere end de officielle tal. Kirkeministeriet og Danmarks Statistik angiver fx, at der var 8.810 udmeldte i 2007, mens indeværende undersøgelse identificerer 11.470, altså 2.660 flere. Forskellen skyldtes formentlig forskellige måder at opgøre tallene på. At der er flere udmeldte i registerudtrækket, burde være uden betydning for analyserne, da det ikke er antallet, men de udmeldtes socioøkonomiske profil, som analyseres.

\section{Aldersprofil}

Det kan diskuteres, om de udmeldte var yngre end resten af befolkningen. Gennemsnitsalderen for de udmeldte var 41 år, mens den for resten af befolkningen var 39 år. Set fra den vinkel var de udmeldte rent faktisk ældre end resten af befolkningen. Ser man nærmere på aldersdistributionerne for de to grupper, er konklusionen mere nuanceret. I Figur 1 er opgjort antallet af individer fordelt på aldersgrupper for henholdsvis de udmeldte og kontrolgruppen. De grå søjler repræsenterer kontrolgruppen, og de sorte repræsenterer gruppen af udmeldte. Man skal bemærke, at søjlerne for kontrolgruppen, altså de grå søjler, er omkring 10 gange for små i forhold til befolkningen som helhed, men det er i og for sig irrelevant. Det interessante er mønstret i de to rækker af søjler. Kontrolgruppen havde en aldersfordeling, som man ville forvente for et postindustrielt land. Omtrent lige mange unge som midaldrende og med færre og færre individer, som alderen når over de 65 år. Dette ville give den karakteristiske flaskeform, hvis tallene var opretstående og kønsopdelt, som demo- 
grafiske pyramider plejer at være. Ser man på de udmeldte, repræsenteret ved de sorte søjler, var der næsten ingen børn og næsten ingen over pensionsalderen. Et flertal på 65 pct. af de udmeldte var mellem 25 og 49 år gamle. De tre største alderskategorier, dvs. de tre højeste mørke søjler i Figur 1, udgjordes af de 30 til 44-årige. Denne gruppe udgjorde ca. 44 pct. af de udmeldte. Omkring 24 pct. af de udmeldte var 50 år og opefter, mens kun 11 pct. var under 25 år gamle. Ser man bort fra børn, dvs. individer under 18 år, var gennemsnitsalderen for de udmeldte 42 år, mens den var 48 år for resten af befolkningen. Set fra den vinkel var de udmeldte rent faktisk yngre end resten af befolkningen. Under alle omstændigheder er det svært at argumentere for, at der var en simpel sammenhæng mellem at melde sig ud af folkekirken og at tilhøre en yngre generation, hvilket jo var argumentationen bag hypotese $\mathrm{H}_{1}$.

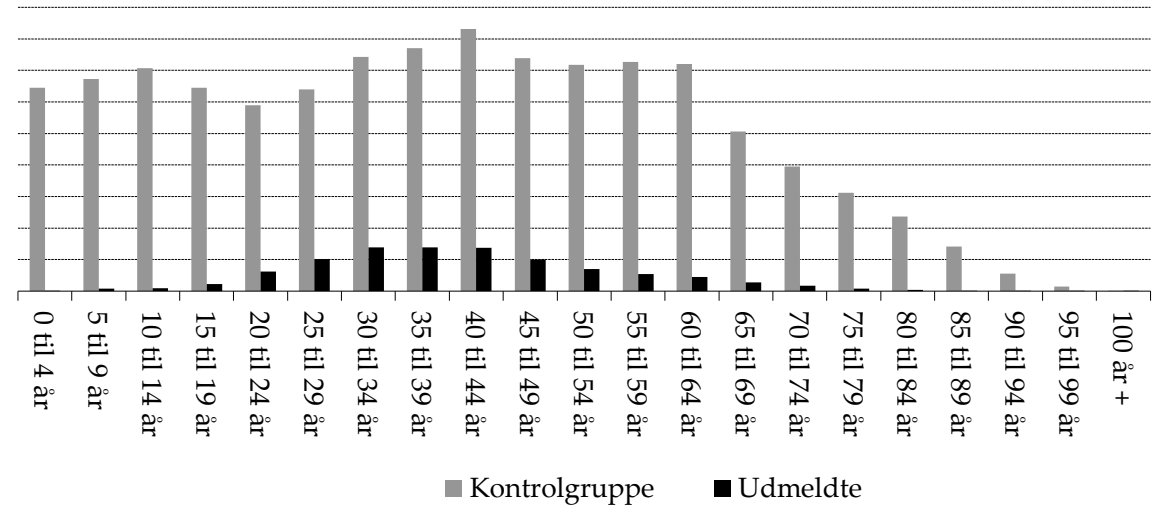

Figur 1: Aldersfordeling af udmeldte og kontrolgruppe (i rå tal); Kilde: Danmarks Statistik

Der er formentlig to forklaringer på aldersfordelingen blandt de udmeldte. Som loven var, og stadig er, kunne individer kun melde sig ud af folkekirken, efter de var fyldt 18 år. For individer under 15 år er ind- og udmeldelse suverænt forældrenes beslutning. For individer mellem 15 og 17 år var det stadig forældrenes beslutning; men individet skulle give samtykke. Spørgsmålet er, hvor mange forældre som ville døbe deres barn blot for at melde det ud, før det var fyldt 18. Som det kan ses af Figur 1, var det ikke mange. Det betyder, at udmeldelse først bliver en reel mulighed, når individet er fyldt 18 år, hvorfor der var så få børn og unge blandt de udmeldte.

Undersøgelser fra de andre nordiske lande har vist, at udmeldelse fra en national kirke er slutresultatet af en længere fremmedgørelsesproces. Processen starter med, at individet langsomt mister kontakten til kirken og fx holder op med at komme til gudstjeneste. Senere mister individet også sin kirkerelaterede religiøsitet og holder fx op med at tro på Gud. Efter individet har mistet både kontakt og trosfællesskab med kirken, er vedkommende subjektivt udmeldt. I den tilstand kan en mere eller mindre tilfældig begivenhed give det sidste skub og få individet til objektivt at melde sig ud 
(Bromander 2005). I en dansk kontekst kunne den afgørende begivenhed fx være debatten om flygtningene i Brorson kirke eller om kirkelig vielse af homoseksuelle. Fra individer mister deres kirkelige tilhørsforhold til de eventuelt tager den institutionelle konsekvens af det, kan der gå adskillige år. Det er formentlig derfor, at individer først begynder at melde sig ud, når de er rundet de 25 år. Fra det øjeblik de reelt kan melde sig ud og til de rent faktisk gør det, går der nogle år. De skal først gennemgå den kirkelige fremmedgørelsesproces, før udmeldelsen kan blive en realitet.

Figur 1 antyder eksistensen af et udmeldelses-vindue. Få meldte sig ud i deres barndom eller tidligere ungdom. Omvendt valgte kun få individer at melde sig ud, når først de var fyldt 50 år. De fleste tog beslutningen om at melde sig ud af folkekirken, da de var mellem 25 og 49 år gamle. Det antyder, at der er tale om en form for livscykluseffekt, hvor hypotesen forudsatte en generationseffekt. En sådan kan godt eksistere sideløbende med livscykluseffekten; men det vil kræve data over længere tid at identificere den. I så fald skulle der være et generelt stigende antal udmeldelser over en længere årrække. Hypotese $\mathrm{H}_{1}$ må nok bekræftes; men dens forudsætning om et religiøst generationsskifte må afvises.

\section{Indkomst, uddannelse og geografi}

Fordi det først er muligt at melde sig ud af folkekirken, når man er fyldt 18 år, er individer under 18 år fjernet fra de følgende analyser (Tabel 2 til 5). Dels ville det skævvride sammenligninger af $\mathrm{fx}$ uddannelse og indkomst at medtage individer under 18 år; dels er en udmeldelse før det 18. leveår højst sandsynligt et udtryk for forældrenes socioøkonomiske profil og ikke den udmeldtes.

\begin{tabular}{lccccccc} 
& & 100.001 & 200.001 & 300.001 & 400.001 & & \\
& Op til & - & - & - & - & Over & \\
& 100.000 & 200.000 & 300.000 & 400.000 & 500.000 & 500.000 & Total \\
\hline Kontrolgruppe & $11 \%$ & $30 \%$ & $27 \%$ & $19 \%$ & $7 \%$ & $7 \%$ & $100 \%$ \\
Udmeldte & $8 \%$ & $22 \%$ & $23 \%$ & $22 \%$ & $11 \%$ & $14 \%$ & $100 \%$ \\
\hline
\end{tabular}

Tabel 2: Årlig bruttoindkomst (i pct.)

Indkomst fordelt på intervaller à $100.000 \mathrm{kr}$.

Kilde: Danmarks Statistik

Individer 18 år og opefter

På trods af, at de udmeldte havde en lavere gennemsnitsalder, når man ser bort fra alle under 18 år, og derfor kortere anciennitet på arbejdsmarkedet, var de generelt mere velhavende end resten af befolkningen. Hypotese $\mathrm{H}_{2}$ er hermed bekræftet. Hvor den gennemsnitlige årlige bruttoindkomst for voksne danskere i 2006 var 272.000 kr., var den 346.000 kr. blandt de voksne udmeldte. De udmeldte tjente altså i snit $74.000 \mathrm{kr}$. mere om året end resten af befolkningen. Der, hvor forskellen for alvor 
slog igennem, var blandt de meget høje indkomster. I befolkningen som helhed havde 7 pct. en årlig bruttoindkomst på over en halv million, mens det var 14 pct. blandt de udmeldte (Tabel 2). Omvendt tjente 41 pct. af danskernes $200.000 \mathrm{kr}$. om året eller mindre, mens det var 30 pct. blandt de udmeldte. Generelt kan man sige, at de udmeldte havde en overvægt af individer, der tjente over $400.000 \mathrm{kr}$. om året. Det er ikke dermed sagt, at kun velhavende individer meldte sig ud af folkekirken. Som Tabel 2 viser, var næsten en tredjedel af de udmeldte i lavindkomstgruppen. Den generelle tendens var dog klar og viste, at meget velhavende individer var mere tilbøjelige til at melde sig ud af folkekirken.

\begin{tabular}{lcccccc} 
& $\begin{array}{c}\text { Grund- } \\
\text { skole }\end{array}$ & $\begin{array}{c}\text { Gymna- } \\
\text { sial }\end{array}$ & $\begin{array}{c}\text { Er- } \\
\text { hvervs- } \\
\text { faglig }\end{array}$ & $\begin{array}{c}1-3 \text { år } \\
\text { videre- } \\
\text { gånde }\end{array}$ & $\begin{array}{c}\text { Universi- } \\
\text { tetsgrad }\end{array}$ & Total \\
\hline Kontrolgruppe & $33 \%$ & $8 \%$ & $35 \%$ & $19 \%$ & $6 \%$ & $100 \%$ \\
Udmeldte & $21 \%$ & $12 \%$ & $28 \%$ & $25 \%$ & $14 \%$ & $100 \%$ \\
\hline
\end{tabular}

Tabel 3: Højeste gennemførte uddannelse (i pct.)

Kilde: Danmarks Statistik

Individer 18 år og opefter

De udmeldte var generelt højere uddannede end resten af befolkningen (Tabel 3), præcis som hypotese $\mathrm{H}_{3}$ forventede. Forskellene mellem de udmeldte og resten af befolkningen var mest markante i bunden og toppen af uddannelsessystemet. Hvor en tredjedel af danskerne i 2007 kun havde en grundskoleuddannelse, var det en femtedel blandt de udmeldte. Omvendt havde 14 pct. af de udmeldte en kandidateller ph.d.-grad, mens det var 6 pct. i befolkningen som helhed. Det viser, at de, som var mest videnskabeligt skolet og derfor mest influeret af en rationel måde at tænke på, også havde den største tendens til at melde sig ud af folkekirken.

\begin{tabular}{lccccc} 
& $\begin{array}{c}\text { København } \\
\text { \& Frede- } \\
\text { riksberg } \\
\text { kommuner }\end{array}$ & $\begin{array}{c}\text { Resterende } \\
\text { Sjælland og } \\
\text { Bornholm }\end{array}$ & Fyn & Jylland & Total \\
\hline Kontrolgruppe & $13 \%$ & $33 \%$ & $9 \%$ & $46 \%$ & $100 \%$ \\
Udmeldte & $21 \%$ & $33 \%$ & $8 \%$ & $37 \%$ & $100 \%$ \\
\hline
\end{tabular}

Tabel 4: Landsdel for bopæl (i pct.)

Kilde: Danmarks Statistik

Individer 18 år og opefter

De, som meldte sig ud af folkekirken fra 2003 til 2007, havde en distinkt geografisk profil. Hvor 13 pct. blandt voksne danskerne i 2007 boede i Københavns eller Frederiksberg kommuner, var det 21 pct. blandt de udmeldte (Tabel 4). Til gengæld boede 
37 pct. af de udmeldte i Jylland mod 46 pct. blandt resten af befolkningen. Andelen, som boede på resten af Sjælland inklusiv Københavns forstæder eller på Fyn, var omtrent den samme for begge grupper. Det var karakteristisk, at de udmeldte havde en større tilbøjelighed til at bo i København og Frederiksberg kommuner. Hermed er hypotese $\mathrm{H}_{4}$ bekræftet, idet en større andel blandt de udmeldte boede i en større by end resten af befolkningen. Der var næppe tale om et modsætningsforhold mellem provinsbyerne og hovedstaden som sådan eller om afstanden til magtens centrum. Det var storbyen København/Frederiksberg, som var det afgørende. Andelen blandt de udmeldte, som boede i Københavns forstæder, var den samme som for resten af befolkningen. Ser man separat på de større byer i Danmark, var billedet det samme. Andelen blandt udmeldte og resten af befolkningen som boede i Århus, Odense og Aalborg kommuner var omtrent den samme. Det viste sig også, at andelene, som boede i Frederiksberg kommune, var næsten lige store for udmeldte som for resten af befolkningen. Der var altså noget ved at bo i selve Københavns kommune, som tiltrak de udmeldte, eller som påvirkede individer til at melde sig ud. Dermed kan hypotese $\mathrm{H}_{4}$ skærpes og omformuleres til, at de udmeldte oftere boede i en storby, idet man kan argumentere for at København er Danmarks eneste reelle storby.

\section{Kernefamilien som faktor}

Som et samfund sekulariseres, isoleres religion i privatsfæren og dermed (kerne)familien. Det betyder, at religiøs påvirkning primært eksisterer, opretholdes og bekræftes i kernefamilien. Hvis det er sandt, burde ikke-religiøse individer blive religiøse af at blive medlemmer af en religiøs kernefamilie fx gennem ægteskab. Omvendt burde religiøse individer miste deres religiøsitet ved at blive gift ind i en ikke-religiøs familie.

\begin{tabular}{lccc} 
& $\begin{array}{c}\text { Partner } \\
\text { ikke- } \\
\text { medlem }\end{array}$ & $\begin{array}{c}\text { Partner } \\
\text { medlem }\end{array}$ & Total \\
\hline Kontrol: Medlem & $11 \%$ & $89 \%$ & $100 \%$ \\
Kontrol: Ikke-medlem & $67 \%$ & $33 \%$ & $100 \%$ \\
\hline Udmeldt & $87 \%$ & $13 \%$ & $100 \%$
\end{tabular}

Tabel 5: Partners folkekirkemedlemskab (i pct.)

Kilde: Danmarks Statistik

Individer 18 år og opefter med partner $i$ sample $(n=38218)$

Brugen af registerdata fra Danmarks Statistik gjorde det muligt at koble en del af individerne i de to grupper med deres samlevere. For både udmeldte og kontrolgruppen var der oplysninger om, hvem de boede sammen med af såvel børn som voksne. Da der sjældent var mere end to voksne i en husstand, må det antages, at 
disse levede sammen i parforhold. Ved at sammenligne samlevendes folkekirkemedlemskab eller mangel på samme kunne der tegnes et mere præcist billede af muligheden for religiøs påvirkning i kernefamilien. Af analytiske hensyn blev individer der levede i parforhold opdelt i tre grupper: De, som var medlemmer af folkekirken, de som ikke var medlemmer, og de som havde meldt sig ud af folkekirken i perioden 2003 til 2007. De to første grupper var taget fra kontrolgruppen, mens den sidste gruppe tilhørte gruppen af udmeldte. Blandt de, som var medlemmer af folkekirken i 2007, boede 89 pct. sammen med en partner, som også var medlem af folkekirken (Tabel 5). Blandt de, som ikke var medlemmer af folkekirken, boede de 67 pct. sammen med en partner, som heller ikke var medlem af folkekirken. Dette antyder, at der fandtes religiøs påvirkning sted i kernefamilien, idet flertallet af danskerne havde en partner med samme forhold til folkekirken som dem selv.

Blandt de, som meldte sig ud af folkekirken i perioden 2003 til 2007, var det karakteristisk, at langt de fleste, 87 pct., levede sammen med en partner, som var ikkemedlem. Dermed kan hypotese $\mathrm{H}_{5}$ bekræftes. At 87 pct. blandt de udmeldte levede sammen med et ikke-medlem, antyder, at tendensen til at melde sig ud af folkekirken var langt større for individer, der ikke kunne få religiøs bekræftelse i hjemmet. Eller omvendt at de udmeldte blev bekræftet og understøttet i deres beslutning om at melde sig ud af folkekirken af den manglende religiøsitet i hjemmet. Det antyder, at den religiøse påvirkning, positiv som negativ, i dag primært findes i kernefamilien, og det bekræfter også, at en del af sekulariseringens påvirkning på individniveau sker via manglende religiøs socialisering i hjemmet.

\begin{tabular}{lccc} 
& $\begin{array}{c}\text { Barn ikke } \\
\text { medlem }\end{array}$ & $\begin{array}{c}\text { Barn med- } \\
\text { lem }\end{array}$ & Total \\
\hline Mor ikke-medlem & $74 \%$ & $26 \%$ & $100 \%$ \\
Mor medlem & $8 \%$ & $92 \%$ & $100 \%$ \\
\hline
\end{tabular}

Tabel 6: Mødres og deres børns medlemskab af folkekirken (i pct.)

Kilde: Danmarks Statistik

Individer under 18 år med primærforælder $i$ sample $(n=13240)$

Sidstnævnte kan yderligere bekræftes, omend det ikke direkte relaterer til udmeldelser fra folkekirken. Ligesom visse individer kunne kobles til eventuelle partnere, kunne hjemmeboende børn i visse tilfælde kobles til primærforælder i registerudtrækket. Danmarks Statistik definerer primærforælder som den forælder, barnet bor sammen med. Hvis barnet bor sammen med både en kvinde og en mand, er primærforælderen kvinden. Kun meget få børn i udtrækket boede alene med deres far, så primærforælder var i langt de fleste tilfælde moderen. Af de børn, hvis mødre var medlemmer af folkekirken, var de 92 pct. selv medlemmer (Tabel 6). Af de børn, hvis mødre ikke var medlem af folkekirken, var de 74 pct. heller ikke selv medlemmer. Den overvejende tendens var altså, at børn 'arvede' deres mødres folkekirkemedlem- 
skab eller mangel på samme. Hvis mor var medlem af folkekirken blev barnet døbt og ellers ikke. Tabel 5 og 6 antyder samlet set, at det er manglende religiøs socialisering i hjemmet, som fører til såvel udmeldelser fra folkekirken som manglende indmeldelse i form af navngivning. Og dermed, at manglende religiøs socialisering er en hovedfaktor bag folkekirkens dalende medlemstal.

\section{Konklusion}

Teorier om sekularisering forventer dels, at folkekirken vil miste medlemmer over tid, dels at de, som forlader folkekirken, har en distinkt socioøkonomisk profil. Et hurtigt kig på folkekirkens medlemsstatistik bekræfter at folkekirken har mistet medlemmer over tid. Målet med indeværende analyse var at be- eller afkræfte forventningen om, at det ikke var tilfældigt, hvem som valgte at melde sig ud af folkekirken. Sekulariseringsteori postulerer, at sekularisering påvirker individer med forskellig intensitet, alt efter hvilke grupper i samfundet de er tilknyttet. Konkret forventer sekulariseringsteori, at individer som meldte sig ud af folkekirken, generelt var yngre, rigere, højere uddannede og boede i større byer. Teorien forventer også, at individer i parforhold som meldte sig ud af folkekirken, boede sammen med ikkemedlemmer, fordi den religiøse socialisering primært sker i hjemmet.

For at be- eller afkræfte ovenstående forventninger blev fem hypoteser formuleret og testet på et registerudtræk fra Danmarks statistik. Udtrækket bestod af alle herboende individer, som meldte sig ud af folkekirken i perioden 2003 til 2007 og en kontrolgruppe på 10 pct. af befolkningen. Alle fem hypoteser blev bekræftet, omend med visse nuancer. I forhold til befolkningen som helhed var de udmeldte generelt yngre, rigere og højere uddannede. De udmeldte havde også større sandsynlighed for at bo i en større by og for at bo med en partner, som ikke var medlem af folkekirken.

Bekræftelsen af hypoteserne om de udmeldtes lavere alder og deres bopæl i større byer må dog nuanceres i lyset af den empiriske analyse. De udmeldte var kun yngre end resten af befolkningen, hvis man så bort fra individer under 18 år. Det er i og for sig også rimeligt, eftersom det juridisk set kun er muligt at melde sig ud af folkekirken når man er fyldt 18 år. Før det er en eventuel udmeldelse forældrenes beslutning. En anden nuance var, at udmeldelse ikke umiddelbart var knyttet til en generationseffekt, som teorien forudsatte. Det var ikke sådan, at der var flest blandt de udmeldte, som var mellem 20 og 24 år, og så lidt færre som var mellem 25 og 29 år etc. De udmeldte havde en overvægt af individer mellem 30 og 44 år, hvilket antyder en livscykluseffekt. Dvs. at individer havde tendens til at melde sig ud af folkekirken i en bestemt periode af deres liv. Den empiriske analyse viste, at de udmeldte ikke som sådan var mere tilbøjelige til at bo i større byer. Det distinkte ved de udmeldte var, at de havde større tendens til at bo i København. De kom ikke oftere fra Århus, Odense eller Ålborg. Dette betyder, at hypotesen kan skærpes derved at udmeldte oftere boede i en egentlig storby, af hvilke Danmark kun har én: København. 
Analysen har bekræftet, at sekulariseringsteori kan forklare de socioøkonomiske faktorer bag udmeldelser fra den danske folkekirke. Det antyder, at folkekirkens dalende medlemstal bl.a. er et resultat af en generel samfundsudvikling. Analysen viser også, at udmeldte oftere levede i parforhold med ikke-medlemmer, og at flertallet af ikke-medlemmer navngav deres børn. Dette antyder, at sekularisering bl.a. virker gennem manglende religiøs socialisering i hjemmet. Metodediskussionen og erfaringer fra analyser af medlemsfrafald i de andre nordiske lande viser, at der formentlig er flere faktorer bag udmeldelser fra folkekirken end de socioøkonomiske, som har været fokus i indeværende analyse. Et vigtigt skridt på vejen til en fuldere forståelse af folkekirkens medlemstab ville derfor være at supplere indeværende analyse med såvel kvantitative spørgeskemaundersøgelser som kvalitative interviews af udmeldte fra folkekirken.

\section{LTTERATUR}

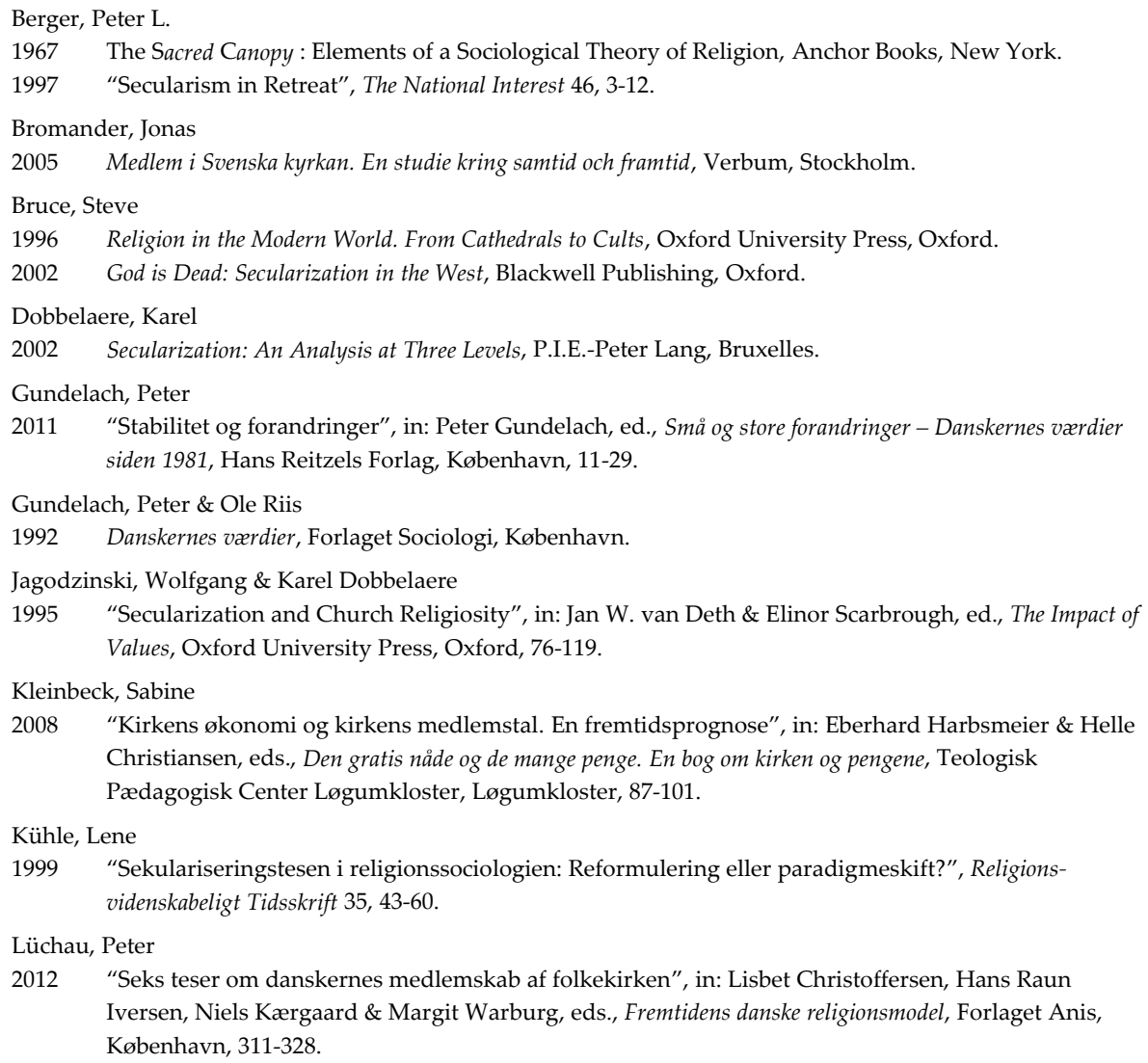

2012 "Seks teser om danskernes medlemskab af folkekirken", in: Lisbet Christoffersen, Hans Raun Iversen, Niels Kærgaard \& Margit Warburg, eds., Fremtidens danske religionsmodel, Forlaget Anis, København, 311-328. 
Lüchau, Peter \& Peter B. Andersen

2012 "Socio-Economic Factors Behind Disaffiliation from the Danish National Church", Nordic Journal of Religion and Society 25 (1), 27-45.

Luckmann, Thomas

1967 The Invisible Religion. The Problem of Religion in Modern Society, The Macmillan Company, New York.

Luhmann, Niklas

1977 Funktion der Religion, Suhrkamp, Frankfurt am Main.

Martin, David

1969 The Religious and the Secular. Studies in Secularization, Routledge \& Kegan Paul, London.

Niemelä, Kati

2007 "Alienated or Disappointed? Reasons for Leaving the Church in Finland", Nordic Journal of Religion and Society 2 (20), 195-216.

Norris, Pippa \& Ronald Inglehart

2004 Sacred and Secular: Religion and Politics Worldwide, Cambridge University Press, New York.

Roof, Wade Clark

1978 Community and Commitment: Religious Plausibility in a Liberal Protestant Church, Elsevier NorthHolland, New York

Shiner, Larry

1967 "The Concept of Secularization in Empirical Research", Journal for the Scientific Study of Religion 6 (2), 207-220.

Sundback, Susan

1989 Sekularisering och kyrkotrohet i Danmark: Ett sociologiskt fallstudium av utträden i Århus 1930-1981, Aarhus Universitetsforlag, Aarhus.

Wilson, Bryan

1966 Religion in Secular Society. A Sociological Comment, C.A. Watts, London.

Peter Lüchau, Post.doc., ph.d. Sociologisk Institut, Københavns Universitet 